\title{
Essential oil of Peumus boldus Molina against the nematode Haemonchus contortus (L3) and three stored cereal insect pests
}

\author{
Gonzalo Silva-Aguayo $^{1^{*}}$, Liliana Aguilar-Marcelino ${ }^{2}$, Edgar Cuevas-Padilla ${ }^{2}$, Patricia Loyola-Zapata ${ }^{1}$, \\ J. Concepción Rodríguez-Maciel ${ }^{3}$, Gloria Castañeda-Ramírez ${ }^{2}$, and Inés Figueroa-Cares ${ }^{1}$
}

\begin{abstract}
${ }^{1}$ Universidad de Concepción, Facultad de Agronomía, Av. Vicente Méndez 595, Chillán, Chile. "Corresponding author (gosilva@udec.cl). ${ }^{2}$ Instituto Nacional de Investigaciones Forestales y Agropecuarias (INIFAP), CENID-Salud Animal e Inocuidad, km 11 Carretera Federal Cuernavaca-Cuautla, Nº534, Col. Progreso, Jiutepec, Morelos, CP 62550, México.

${ }^{3}$ Colegio de Postgraduados, Programa de Fitosanidad, Carretera Federal México-Texcoco km 36,5, Texcoco, Estado de México, México.
\end{abstract}

Received: 5 February 2021; Accepted: 29 April 2021; doi:10.4067/S0718-58392021000300390

\begin{abstract}
Alternative methods of control against different parasites affecting livestock and agriculture are currently being sought. The essential oil of Peumus boldus Molina has anthelmintic and insecticidal activity against the nematode Haemonchus contortus and stored cereal insect pests. The present study aimed to assess the in vitro activity of P. boldus essential oil against H. contortus (L3) unsheathed and Sitophilus zeamais, Tribolium castaneum, and Plodia interpunctella. The essential oil was obtained from leaves of $P$. boldus and its principal compounds identified by phytochemical analysis. Essential oil was tested at concentrations of $0.25,0.5,0.75,1.0,1.25,1.5,1.75$ and $2.0 \mathrm{mg} \mathrm{mL}^{-1}$ on unsheathed $\mathrm{L} 3 \mathrm{H}$. contortus larvae and in concentrations of $0,35,70,100,125,150,175$ and $200 \mu \mathrm{L} \mathrm{L}^{-1}$ air on adult insects. The main constituents detected in the essential oil were 1,8-cineole, terpineol, terpinene-4-ol, $\gamma$-terpinene, $p$-cimene, methyl eugenol, safrole, $(E)$-germacrene $\mathrm{D}$, $\beta$-tujene, and ascaridol. The nematode $H$. contortus and insects were exposed to the essential oil for $72 \mathrm{~h}$. In a bioassay with H. contortus larvae, treatment with $2.0 \mathrm{mg} \mathrm{mL}^{-1}$ showed the highest toxicity with $99.2 \%$ mortality. Regarding insecticidal activity, S. zeamais was the most susceptible species with a mortality of $90 \%$ at $200 \mu \mathrm{L} \mathrm{L}^{-1}$ air. The present study suggests that the essential oil of $P$. boldus has potential anthelmintic and insecticidal activity.
\end{abstract}

Key words: Natural products, nematode, Plodia interpunctella, Sitophilus zeamais, stored cereal pests, Tribolium castaneum.

\section{INTRODUCTION}

The meat industry requires that animals and cereals they consume be maintained in a state of good health, but livestock and grains have parasites that affect their economy. In livestock, the nematode Haemonchus contortus (Rudolphi, 1803) Cobb (Strongylida: Trichostrongylidae) is a hematophagous parasite that causes histological damage to the abomasum, producing anemia; it can be fatal to young animals, causing significant economic losses worldwide (Pineda-Alegría et al., 2017). The main methods of combatting nematode infection are chemical treatments. However, frequent and excessive doses of anthelmintics have caused anthelmintic resistance. Interest has arisen in natural products of plant origin due to the undesirable side-effects of chemicals on non-target organisms, environmental hazards, and the development of resistance.

In the case of stored cereals, insects such as Tribolium castaneum Herbst (Coleoptera: Tenebrionidae), Sitophilus zeamais Motschulsky (Coleoptera: Curculionidae), and Plodia interpunctella Hubner (Lepidoptera: Pyralidae) affect flour, maize, wheat, and rice, among others, generating economic losses. The loss of stored grains due to insect damage is estimated between 5\% and 10\% of worldwide production (Mesterházy et al., 2020), and its control is usually performed with synthetic insecticides, leading to critical problems such as the presence of undesirable residues on food and resistance development mainly to phosphine the main insecticide used in warehouse pest control (Agrafioti et al., 2019). 
Essential oils from plants can be an alternative means of parasite and insect control. Against $H$. contortus, they have been assessed for effectiveness in treating animal diseases and as a nutraceutical alternative in ruminant nutrition. As for the anthelmintic activity of essential oils, it has been reported in previous studies with sheep that the essential oils of Lippia sidoide Cham., Citrus xsinensis (L.) Osbeck, Cymbopogon schoenanthus (L.) Spreng., and Eucalyptus staigeriana F. Muell. ex F.M. Bailey. They reduce fecal egg counts load of $H$. contortus with an effect of $30 \%, 97 \%$, 60\%, and 99\%, respectively (Squires et al., 2010; Macedo et al., 2010).

Many studies have demonstrated contact and fumigant toxicity of plant essential oils and their components to several species of stored product insects at different life stages. Essential oils of plants as Eucalyptus genus against Sitophilus oryzae L. (Coleoptera: Curculionidae) and T. castaneum (Adak et al., 2020), Mentha xpiperita L. against T. castaneum, Lasioderma sericoides (Fabricius) (Coleoptera: Anobiidae) and Liposcelis bostrychophila Badonnel (Psocoptera: Liposcelididae) (Pang et al., 2019), or Chenopodium ambrosioides L. against S. zeamais (Chu et al., 2011), among others.

Boldus (Peumus boldus Molina; Monimiaceae) is known worldwide for its therapeutic properties. According to pharmacopeias and treatises dealing with medicinal plants, boldo extracts have been used to treat headache, earache, rheumatism, "nervous weakness", dropsy, dyspepsia, menstrual pain, urinary tract inflammation and has also been claimed to be a sedative and mildly hypnotic. Its active components include alkaloids, essential oils, and flavonoids with boldine being the best-known alkaloid component (Benedetti-Ruiz and Barros-Asenjo, 2011). Specifically, leaves and bark contain its alkaloids known collectively as boldine, but boldo leaves contain between $0.4 \%$ and $0.5 \%$ of at least 17 different alkaloids belonging to the large benzylisoquinoline-derived family. Boldine is the major alkaloid as it accounts for $12 \%-19 \%$ of the total alkaloid content, which is considered to have antioxidant, anti-inflammatory, and antipyretic properties. Boldus as well have essential oils and some $45 \%$ to $53 \%$ of the oil is composed of ascaridole, 1,8-cineole, limonene, $\alpha$-terpineol, and terpinen-4-ol (Pavela et al., 2019).

Thus, boldus essential oil is a candidate to assess its anthelmintic potential against the parasite $H$. contortus According to Delgado-Díaz and Jara (2018), P. boldus has demonstrated anthelmintic activity against Ascaris suum Goeze. These authors assessed the efficacy of a hydroalcoholic extract of $P$. boldus leaves against eggs and larvae of A. suum, concluding that extract showed the same effectiveness as piperazine citrate, a drug used as an anthelmintic in some countries. Furthermore, Junkuszew et al. (2017) evaluated a formulation with essential oil of $P$. boldus against gastrointestinal parasites, obtained a reduction of the prevalence of Eimeria and Capillaria similar to a synthetic chemical agent containing albendazole. Finally, according to French (2018), P. boldus with Achillea millefolium L., Dryopteris filix-mas (L.) Schott, Rosmarinus officinalis (L.) Schleid., and Salvia officinalis L. are the top five plants with the highest number of anthelmintic compounds.

Regarding insecticidal activity, studies have shown that the powder, extracts and essential oil of $P$. boldus have contact and fumigant toxicity and insectistatic activity as repellent (Pizarro et al., 2014). Chiffelle et al. (2019) with an ethanolic extract inhibited feeding behavior of Xanthogaleruca luteola Müller (Coleoptera: Chrysomelidae) larvae. Pavela et al. (2019) indicated toxicity of P. boldus essential oil against Musca domestica L. (Diptera: Muscidae) and Culex quinquefasciatus Say (Diptera: Culicidae), Sombra et al. (2020) obtained ovicidal and pupicidal activity against Spodoptera frugiperda (J.E. Smith) (Lepidoptera: Noctuidae) and Pizarro et al. (2014) found insecticidal activity against $S$. zeamais. Therefore, the study aimed to assess the in vitro insecticidal and nematicidal activity of $P$. boldus essential oil.

\section{MATERIALS AND METHODS}

\section{Essential oil}

The essential oil of Peumus boldus Molina was extracted from leaves collected in the field of the Los Lleuques zone (36 51'18'S, 71³8'34" W; 286 m a.s.1.), foothills of Nuble Region, Chile. The collection was carried out during January 2019. The taxonomic identification of collected foliage was verified according to reference vouchers CONC-CH5492 deposited in the herbarium of the Faculty of Agronomy, University of Concepcion at Chillán. Once in the laboratory, only mature, whole leaves were washed with distilled water and dehydrated at $40^{\circ} \mathrm{C}$ in a stove (Memmert Gmbh, UNB 500, Schwabach, Germany). The essential oils were obtained by $4 \mathrm{~h}$ of steam distillation using distilled water in a Clevenger-type apparatus. Subsequently, the oil was treated with sodium sulfate to eliminate residual water and stored in amber-colored glass containers at $4.5^{\circ} \mathrm{C}$. The chemical analysis of essential oil was carried out at the Laboratory of Pharmacognosy at the Faculty of Pharmacy, University of Concepcion, Concepción, Chile. The essential oil of P. boldus was assessed by 
gas chromatography (GC) coupled to mass spectrometry (GC-MS), using a high-performance gas chromatographer-mass spectrometer (HPGC-MS; HP 5890 Series II, Hewlett Packard, Palo Alto, California, USA).

\section{Production of infecting larvae (L3) of Haemonchus contortus}

The isolate used for Haemonchus contortus was "Hueytamalco", belonging to the Department of Helminthology, Centro Nacional de Investigación Disciplinaria (CENID)-Salud Animal e Inocuidad, Instituto Nacional de Investigaciones Forestales y Agropecuarias (INIFAP), México. This strain was isolated from the feces of a sheep naturally infected by $H$. contortus in Hueytamalco, municipality of the State of Puebla, Mexico (Pineda-Alegría et al., 2017). To obtain infectious larvae of the nematode $H$. contortus, 3-mo-old sheep free of parasites were selected. The animals were obtained from the INIFAP institute, and this work complies with the ethical standards of the relevant Mexican guidelines regarding animal welfare and unnecessary animal suffering; these are well-established Good Management Practice policies at our institution. Sheep were infected orally with infectious larvae (L3) of H. contortus (at $350 \mathrm{~L}^{3} \mathrm{~kg}^{-1}$ body weight) and were used as egg-donor sheep (Liébano-Hernández et al., 2011). After 21 d, the McMaster technique was performed to confirm and determine the number of eggs per gram of feces. Once the presence of $H$. contortus was confirmed in the feces, the donor animal was placed in a metabolic cage. The feces of the donor animal were collected for coproculture, which was left to incubate for $7 \mathrm{~d}$ at $28^{\circ} \mathrm{C}$, then larvae (L3) were recovered using the Baermann technique. These larvae were stored refrigerated at $11^{\circ} \mathrm{C}$ until use in bioassays. After the studies, sheep were dewormed and could continue with the planned cycle. These animals were not slaughtered. To eliminate $H$. contortus infecting larvae sheath with sodium hypochlorite, commercial sodium hypochlorite at $6 \%$ was used for ensheathment of infected larvae. Then, $10 \mathrm{~mL} 0.187 \%$ chlorine was prepared and larvae were exposed for 9 min. It was observed and quantified that more than $95 \%$ larvae no longer had the sheath. Subsequently, four washes were performed with distilled water, centrifuging for $1 \mathrm{~min}$ at $261.97 \mathrm{rad} \mathrm{s}^{-1}$ to eliminate sodium hypochlorite (González-Cortázar et al., 2020). Once the larvae were washed, the sediment formed in 50 mL Falcon tubes was recovered (Liébano-Hernández et al., 2011).

\section{Insect rearing}

The insecticidal activity was assessed against three biological models: Tribolium castaneum, Sitophilus zeamais and Plodia interpunctella. All insects were obtained from laboratory cultures maintained for the last $10 \mathrm{yr}$ in a bioclimatic chamber (Memmert Gmbh, IPS 749, Schwabach, Germany) at 25-30 ${ }^{\circ} \mathrm{C}, 60 \% \mathrm{RH}$, and in total darkness. Tribolium castaneum adults were reared in 1-L glass containers with wheat flour with a 12\%-13\% moisture content mixed with yeast $(10: 1, \mathrm{w} / \mathrm{w})$. Sitophilus zeamais adults were reared on whole maize at $12 \%-13 \%$ moisture content in 3-L glass containers, and the colony of P. interpunctella was reared on artificial diet of McGaughey and Beeman (1988) containing cornmeal (26\%), whole wheat flour (23\%), glycerol (16\%) honey (14\%), ground dog meal (10\%), brewer's yeast (5\%), rolled oats $(4 \%)$ and wheat germ $(2 \%)$ in 5 -L glass containers.

\section{Anthelmintic activity bioassays}

Ensheathed $H$. contortus L3 larvae were exposed in vitro to the essential oil of $P$. boldus. The experiment was carried out in a multi-well plate (96 wells). First, $50 \mu \mathrm{L}$ essential oil to be evaluated was diluted to different concentrations $(0.25$, $0.5,0.75,1.0,1.25,1.5,1.75$ and $\left.2.0 \mathrm{mg} \mathrm{mL}^{-1}\right)$ in $4 \%$ methanol $(\mathrm{MeOH})$, and $50 \mu \mathrm{L}$ aqueous suspension of ensheathed $\mathrm{L} 3$ larvae of $H$. contortus were added, for a final volume of $100 \mu \mathrm{L}$ and 200 larvae per well. A negative control $(4 \% \mathrm{MeOH})$ and a positive control (ivermectin at $20 \mathrm{mg} \mathrm{mL}^{-1}$ ) were used. The plates were packed with aluminum foil and incubated at $28{ }^{\circ} \mathrm{C}$. Four replicates were made for each treatment. This methodology was used to evaluate different post-confrontation times $(24,48$, and 72 h) (González-Cortázar et al., 2020). After the corresponding hours of exposure, mortality was observed under microscope (40X) by counting live and dead larvae. This quantification was done on slides (10 drops of $10 \mu \mathrm{L}$ ), observing the larvae, counting the degraded larvae and those that did not move when stimulated as dead. The live larvae were counted as those that moved even after incubation.

\section{Insecticidal activity bioassays}

The insecticidal activity of essential oil of P. boldus by inhalation toxicity was assessed against adults of T. castaneum, $S$. zeamais, and P. interpunctella using the method of Pizarro et al. (2014). A $2 \mathrm{~cm}$ diameter filter paper (Whatman $\mathrm{N}^{\circ} 1$ ) was impregnated with essential oil in concentrations of $35,70,100,125,150,175$, and $200 \mu \mathrm{L} \mathrm{L}^{-1}$ air using a micropipette. 
Each filter paper disk was then air-dried for 2 min and placed on the underside of the screw cap of a glass vial. In $T$. castaneum and $S$. zeamais bioassays, 20 adults were placed into 0.5 - $\mathrm{L}$ glass vials before the cap was screwed tightly, and the lid was sealed with parafilm. In experiments with $P$. interpunctella adults, moths were placed individually in $0.15-\mathrm{L}$ glass vials in groups of 20 vials per replicate. Each treatment had 20 replicates, and insect mortality was recorded $72 \mathrm{~h}$ after treatment. The maximum level of mortality accepted for the control was $5 \%$, and the mortality value was corrected using Abbott's formula (Abbott, 1925). An insect was considered dead when it did not move after being prodded with a dissection needle for $5 \mathrm{~min}$. All bioassays were carried out at $25 \pm 1{ }^{\circ} \mathrm{C}, 60 \pm 5 \% \mathrm{RH}$, and 16:8 h photophase.

\section{Data analysis}

In insecticidal and nematicidal bioassays, the experimental design was completely randomized. The mortality rate of ensheathed L3 larvae was calculated by using the formula described by Pineda-Alegría et al. (2017). In the case of anthelmintic activity, a Generalized Linear Model (GLM) was carried out obtaining average mortalities at 24, 48, and $72 \mathrm{~h}$ exposure of L3 of $H$. contortus with the respective evaluated concentrations. Statistical significance was determined by Tukey's post $h o c$ test with significance set at $\mathrm{p}<0.05$. In insecticidal activity bioassays, the percent mortality was transformed into an arcsine function represented by $\sqrt{ } \mathrm{x} / 100$ prior to carrying out ANOVA $(\alpha=0.05)$ to determine if at least one treatment was different from the rest. If so, a Tukey's means comparison test was used ( $\mathrm{p} \leq 0.05)$. To obtain $50 \%\left(\mathrm{LC}_{50}\right)$ and $95 \%$ $\left(\mathrm{LC}_{95}\right)$ lethal concentration of insects and 50\% ( $\left.\mathrm{EC}_{50}\right)$ and $90 \%\left(\mathrm{EC}_{90}\right)$ effective concentration of ensheathed larvae data were subjected to Probit analysis using PROC PROBIT procedure of Statistical Analysis System (SAS). All analyses were submitted with the SAS program (SAS Institute, Cary, North Carolina, USA).

\section{RESULTS AND DISCUSSION}

\section{Chemical analysis of essential oil}

The foliage of $P$. boldus had a yield of $2.0 \%$ because $20 \mathrm{~mL}$ essential oil were obtained from $1 \mathrm{~kg}$ dry leaves. A total of $51.7 \%$ of components were identified (Table 1) and the remaining $48.3 \%$ were indicated as unknown by chromatography, but none exceeded $1.0 \%$ composition. The main components identified were ascaridol (24.37\%), 1,8-cineole (14.85\%), terpineol (2.14\%), terpinene-4-ol (3.37\%), $\gamma$-terpinene (3.94\%) and safrole (1.45\%) (Table 1).

\section{Anthelmintic activity}

Exposure of $H$. contortus larvae to the essential oil of $P$. boldus at $2 \mathrm{mg} \mathrm{mL}^{-1}$ resulted in $77.63 \%$ mortality after $24 \mathrm{~h}$, $77.97 \%$ after $48 \mathrm{~h}$, and $99.25 \%$ after $72 \mathrm{~h}$ (Table 2). In addition, $P$. boldus essential oil resulted in a mortality rate of $90 \%$ to $1.5 \mathrm{mg} \mathrm{mL}^{-1}$ at $72 \mathrm{~h}$. The lowest $\mathrm{EC}_{50}$ was for $P$. boldus oil at $72 \mathrm{~h}\left(0.99 \mathrm{mg} \mathrm{mL}^{-1}\right)$. At $72 \mathrm{~h}$ exposure, $\mathrm{EC}_{99}$ was $1.91 \mathrm{mg} \mathrm{mL}^{-1}$ (Table 3).

The anthelmintic activity obtained from P. boldus agrees with a study against Ascaris suum (Delgado-Díaz and Jara, 2018). The activity of some of the constituents of $P$. boldus present in this study, such as ascaridol, 1,8-cineole, $p$-cimene, and methyl eugenol, among others, against $H$. contortus has been reported previously. Ascaridol was documented as an active molecule against Ascaris (Harder, 2002). This component is a bicyclic monoterpene that acts like many other terpenoids paralyzing and narcotizing the intestinal endoparasite, facilitating its expulsion by intestinal peristalsis of the host (Delgado-Díaz and Jara, 2018). The constituent 1,8-cineole, eugenol, p-cimene reported in P. boldus can also be detected in other plants reported to have anthelmintic activity. The species Ocimum gratissimum L. was assessed in vitro hatching tests against $H$. contortus, and among its main documented constituents were eugenol and 1,8-cineole. The essential oil of this plant was reported to have anti-hatching activity, but the most prominent activity was for eugenol with a $94 \%$ inhibition against $H$. contortus at a concentration of $0.25 \%$ (Pessoa et al., 2002). In the evaluation of the essential oil of Artemisia lancea Vaniot with 1,8-cineole as the principal component, the anti-hatching activity was 99\% inhibition at $10 \mathrm{mg} \mathrm{mL}^{-1}$, and the effective concentration to inhibit egg hatching was $1.82 \mathrm{mg} \mathrm{mL}^{-1}$. When 1,8-cineole was assessed isolated presented an anti-hatching activity of $\mathrm{CE}_{50} 4.64 \mathrm{mg} \mathrm{mL}^{-1}$. In addition, Arisaema franchetianum Engl. oil and A. lobatum Engl. with 1,8-cineole as more abundant chemical compounds in its essential oils showed an activity of $77 \%$ and 95\% in larval development trials at $10 \mathrm{mg} \mathrm{mL}^{-1}$ (Zhu et al., 2013). 
Table 1. Main constituents of essential oil from Peumus boldus determined by gas chromatography and gas chromatography-mass spectrometry detection.

\begin{tabular}{lc}
\hline Compound & $\%$ \\
\hline Ascaridol & 24.37 \\
1,8-Cineole & 14.85 \\
$\gamma$-Terpinene & 3.94 \\
Terpinene-4-ol & 3.37 \\
Terpineol & 2.14 \\
Safrole & 1.45 \\
Methyleugenol & 0.46 \\
(E)-Germacrene D & 0.45 \\
$\beta$-Tujene & 0.32 \\
$p$-Cimene & 0.21 \\
Isoterpinolene & 0.10 \\
Linalool & 0.10 \\
\hline Total & 51.70 \\
\hline
\end{tabular}

Table 2. Mortality of Haemonchus contortus larvae after 24, 48, and $72 \mathrm{~h}$ treated with different concentrations of Peumus boldus essential oil.

\begin{tabular}{lcccc}
\hline & & \multicolumn{3}{c}{ Mortality } \\
\cline { 3 - 5 } Treatment & Concentration & $24 \mathrm{~h}$ & $48 \mathrm{~h}$ & $72 \mathrm{~h}$ \\
\hline & $\mathrm{mg} \mathrm{L}^{-1}$ & $0.00 \mathrm{a}$ & $0.00 \mathrm{a}$ & $0.00 \mathrm{a}$ \\
Metanol (4\%) & & $3.13 \mathrm{ab}$ & $6.31 \mathrm{~b}$ & $3.04 \mathrm{a}$ \\
P. boldus essential oil & 0.25 & $5.75 \mathrm{~b}$ & $8.42 \mathrm{~b}$ & $15.11 \mathrm{~b}$ \\
& 0.50 & $12.10 \mathrm{c}$ & $16.48 \mathrm{c}$ & $28.31 \mathrm{c}$ \\
& 0.75 & $13.90 \mathrm{c}$ & $33.35 \mathrm{~d}$ & $38.46 \mathrm{~d}$ \\
& 1.00 & $16.60 \mathrm{c}$ & $64.98 \mathrm{e}$ & $78.97 \mathrm{e}$ \\
& 1.25 & $36.70 \mathrm{~d}$ & $68.57 \mathrm{e}$ & $90.75 \mathrm{f}$ \\
& 1.50 & $69.22 \mathrm{e}$ & $81.20 \mathrm{f}$ & $99.32 \mathrm{~g}$ \\
Ivermectin & 1.75 & $77.63 \mathrm{f}$ & $77.97 \mathrm{f}$ & $99.25 \mathrm{~g}$ \\
SE & 2.00 & $100.00 \mathrm{~g}$ & $100.00 \mathrm{~g}$ & $100.00 \mathrm{~g}$ \\
& 20.00 & 1.58 & 1.62 & 1.72 \\
\hline
\end{tabular}

Values with the same letter are not significantly different according to Tukey's test $(\mathrm{p}<0.05)$.

SE: Standard error.

Table 3. Effective concentration $50 \%\left(\mathrm{EC}_{50}\right)$ and $99 \%\left(\mathrm{EC}_{99}\right)$ and $95 \%$ confidence intervals $(\mathrm{CI})$ of different treatments of essential oil Peumus boldus against Haemonchus contortus L3.

\begin{tabular}{lccccc}
\hline Essential oil & Time & $\mathrm{EC}_{50}$ & $\mathrm{CI}$ & $\mathrm{EC}_{99}$ & $\mathrm{CI}$ \\
\hline \multirow{3}{*}{ P. boldus } & $\mathrm{h}$ & $\mathrm{mg} \mathrm{mL}^{-1}$ & & $\mathrm{mg} \mathrm{mL}$ & \\
& 24 & $1.63 \mathrm{c}$ & $1.59-1.67$ & $3.06 \mathrm{~b}$ & $2.81-3.43$ \\
& 48 & $1.20 \mathrm{~b}$ & $1.16-1.24$ & $3.70 \mathrm{~b}$ & $3.38-4.13$ \\
& 72 & $0.99 \mathrm{a}$ & $0.94-1.02$ & $2.03 \mathrm{a}$ & $1.91-2.18$ \\
\hline
\end{tabular}

Values with the same letter in column are not significantly different according to Tukey's test $(\mathrm{P}<0.05)$.

The E. staigeriana shares with boldo the components limonene, 1,8-cineole, and cimene, and an extract was assessed in a hatching test against $H$. contortus and a larval development test, obtaining $99 \%$ inhibition of hatching at $1 \mathrm{mg} \mathrm{mL}^{-1}$ and $98 \%$ inhibition of larval development at $8 \mathrm{mg} \mathrm{mL}^{-1}$. The anthelmintic activity was attributed to the presence of limonene (Ribeiro et al., 2013). Piper aduncum L. plant has monoterpenes, sesquiterpenes, and 1,8-cineole as main chemical components, it was assessed in vitro in a hatching test against $H$. contortus and showed $89 \%$ inhibitory activity at $6 \mathrm{mg} \mathrm{mL}^{-1}$, this biological activity was attributed to these compounds (Oliveira et al., 2014). It is worth mentioning that the previously reported molecules were found in essential oils of other plants exhibiting promising biopesticidal activity. Essential oils contain highly volatile secondary metabolites that reach a mass less than their molecular weight of $300 \mathrm{Da}$. This supports the hypothesis that some bioactive compound could cause this ovicidal effect with a sufficiently small size (less than 600 Da) to penetrate and kill the egg in the morula phase (Vargas-Magaña et al., 2014). In addition, the advantage of this size is that compounds can accumulate in effective concentrations in nematodes (D'Almeida et al., 2014). 


\section{Insecticidal activity}

The insecticidal activity obtained by fumigation with essential oil of P. boldus was higher against $S$. zeamais, with a mortality of $90 \%$ at concentrations equal to or greater than $125 \mu \mathrm{L} \mathrm{L}^{-1}$ air, and there was nonsignificant difference ( $\mathrm{p}>0.05$ ) between treatments (Table 4). In P. interpunctella, toxicity did not reach $30 \%$ of dead insects, and in $T$. castaneum, the maximum assessed concentration showed a mortality of $30 \%$ (Table 4). The highest toxicity of P. boldus essential oil against $S$. zeamais was observed more clearly when comparing $\mathrm{CL}_{50}$ because the values were 2.67, 2.70, and $1.60 \mu \mathrm{L}$ essential oil $\mathrm{L}^{-1}$ air for T. castaneum, P. interpunctella, and S. zeamais, respectively (Table 5). Results with S. zeamais agree with Pizarro et al. (2014), who obtained $100 \%$ mortality with $20 \mu \mathrm{L}$ essential oil $\mathrm{L}^{-1}$ air. The observed toxicity was mainly due to the action of ascaridole and 1,8-cineole present in the essential oil at $24.37 \%$ and $14.85 \%$, respectively. Chu et al. (2011) obtained the strongest fumigant activity against $S$. zeamais adults with $(Z)$-ascaridole with a $\mathrm{LC}_{50}$ value of $0.84 \mathrm{mg} \mathrm{L}^{-1}$ air, followed by isoascaridole with an $\mathrm{LC}_{50}$ value of $2.45 \mathrm{mg} \mathrm{L}^{-1}$ air. Zhu et al. (2012) in bioassays with Blattella germanica L. (Blattodea: Blattidae) male adults obtained a $\mathrm{LC}_{50}$ of $0.55 \mathrm{mg} \mathrm{L}^{-1}$ air for ascaridole and $2.07 \mathrm{mg} \mathrm{L}^{-1}$ air in isoascaridole with maximum mortality of $100 \%$. Concerning the insecticidal mode of action, de Castro et al. (2016) in larvae of Culex quinquefasciatus treated with essential oil of P. boldus with $89.5 \%$ ascaridole found morphological changes in the midgut, with cells possessing a cytoplasm that contained small vacuole-like structures, as well as a nucleus with decondensed chromatin and a cell apex with a short brush border. The fat body cells showed larger protein granules, which were acidophilic relative to the larvae of the control group. In the case of 1,8-cineole, according to Liska et al. (2015), this monoterpenoid has a promising potential for use as a fumigant, inducing excellent results in the control of stored products insects. These authors evaluated 1,8-cineole against the pupal stage of T. castaneum, obtaining a $30 \%$ of mortality but the serial effect of metamorphosis interference showing deforming adults, mainly in male pupae. These deformities were less or more expressed on elytra developed adults while 1,8-cineole concentration increase. In other insects, 1,8-cineole showed 100\% mortality of the red imported fire ant (Solenopsis invicta Buren; Hymenoptera: Formicidae) workers, even at the lowest concentration of $20 \mu \mathrm{L} \mathrm{L}^{-1}$ after $24 \mathrm{~h}$ exposure (Xie et al., 2019). Kumar et al. (2012) assessed the insecticidal effect of 1,8-cineole by fumigation against $M$. domestica obtained for larvae a $\mathrm{CL}_{50}$ of $2.4 \mu \mathrm{L} \mathrm{L}^{-1}$ and $100 \%$ mortality of pupae. According to Isman (2020), toxic and behavioral effects attributed to mono and sesquiterpenes as 1,8-cineole are a consequence of neurotoxicity or interaction with one or more receptors in the arthropod nervous system. Jankowska et al. (2018) indicated that in insects, essential oils cause paralysis followed by death, and the inhibition of acetylcholinesterase is one of the most investigated mechanisms of action. Studies conducted by Xie et al. (2019) found that 1,8-cineole significantly inhibited the acetylcholinesterase activity in the red imported fire ant workers. But Tak and Isman (2015) indicated that 1,8-cineole could stimulate the response of pheromone-sensitive sensilla of American cockroaches (Periplaneta americana L.; Blattodea: Blattidae), receptor cells modulated by octopamine, a neurotransmitter present only in arthropods.

This is the first report of boldo against $H$. contortus, although the main constituents detected in its essential oil has shown potential anthelmintic activity against $H$. contortus forming part of essential oils of other plants. The present study suggests that $P$. boldus essential oil has potential anthelmintic and insecticidal activity against $H$. contortus and S. zeamais, respectively, but further studies may explore in vivo conditions and possible mechanisms of action, and considering high volatility of some compounds, the next step should be to formulate the essential oil as an emulsion or encapsulation to increase its residuality.

Table 4. Insecticidal activity by fumigant effect of Peumus boldus essential oil against Tribolium castaneum, Sitophilus zeamais and Plodia interpunctella.

\begin{tabular}{lccc}
\hline & \multicolumn{3}{c}{ Mortality } \\
\cline { 2 - 4 } Treatment & Tribolium castaneum & Plodia interpunctella & Sitophilus zeamais \\
\hline$\mu \mathrm{L}$ essential oil $\mathrm{L}^{-1}$ air & $\%$ & $\%$ & $\%$ \\
35 & $3.7 \mathrm{~d}$ & $1.3 \mathrm{~d}$ & $55.5 \mathrm{c}$ \\
70 & $4.3 \mathrm{~d}$ & $5.7 \mathrm{~cd}$ & $63.2 \mathrm{bc}$ \\
100 & $5.4 \mathrm{~cd}$ & $8.8 \mathrm{c}$ & $70.3 \mathrm{~b}$ \\
125 & $10.5 \mathrm{bcd}$ & $12.4 \mathrm{bc}$ & $90.3 \mathrm{a}$ \\
150 & $13.1 \mathrm{bc}$ & $16.3 \mathrm{ab}$ & $93.9 \mathrm{a}$ \\
175 & $18.5 \mathrm{~b}$ & $19.9 \mathrm{a}$ & $99.3 \mathrm{a}$ \\
200 & $30.0 \mathrm{a}$ & $21.9 \mathrm{a}$ & $100.0 \mathrm{a}$ \\
\hline
\end{tabular}

Values within a column with the same letter are not significantly different according to Tukey's test $(\mathrm{p}>0.05)$. 
Table 5. Lethal concentration $50 \%\left(\mathrm{CL}_{50}\right)$ and $95 \%\left(\mathrm{CL}_{95}\right)$ by fumigant effect of essential oil of Peumus boldus against Tribolium castaneum, Plodia interpunctella and Sitophilus zeamais.

\begin{tabular}{|c|c|c|c|c|c|c|}
\hline Essential oil & $\mathrm{N}^{1}$ & $\begin{array}{c}\mathrm{CL}_{50} \\
(\text { Lower-Upper })^{2}\end{array}$ & $\begin{array}{c}\text { CL95 } \\
{\text { (Lower-Upper })^{2}}^{2}\end{array}$ & Slope \pm SE & $\chi^{2}$ & Df \\
\hline & & \multicolumn{5}{|c|}{$-\mu \mathrm{L}$ essential oil $\mathrm{L}^{-1}$ air -} \\
\hline T. castaneum & 1400 & $2.67(2.4-4.05)$ & $3.52(2.9-6.9)$ & $1.9 \pm 0.53$ & 0.0003 & 5 \\
\hline P. interpunctella & 1400 & $2.70(2.53-3.04)$ & $3.57(3.17-4.41)$ & $1.9 \pm 0.35$ & 0.0001 & 5 \\
\hline S. zeamais & 1400 & $1.60(0.97-1.78)$ & $2.30(2.07-2.88)$ & $2.5 \pm 0.62$ & 0.0009 & 5 \\
\hline
\end{tabular}

${ }^{1}$ Total number of insects tested in 10 replicates per treatment.

${ }^{2}$ Confidence limits at $95 \%$ of probability.

SE: Standard error; $\chi^{2}$ : chi-square; Df: degrees of freedom.

\section{CONCLUSIONS}

The essential oil of boldo has anthelmintic and insecticidal activity against unsheathed larvae of Haemonchus contortus and adult of Sitophilus zeamais, respectively.

\section{ACKNOWLEDGEMENTS}

This research received partial financial support from two projects of the Fiscal Resources of the Instituto Nacional de Investigaciones Forestales Agrícolas y Pecuarias (INIFAP), Mexico, with numbers 9442232005 and 834432984.

\section{REFERENCES}

Abbott, W.S. 1925. A method of computing the effectiveness of an insecticide. Journal of Economic Entomology 18:265-267. doi:101.1093/jee/18.2.265a.

Adak, T., Barik, N., Patil, N., Pandi, G., Gadratagi, B., Annamalai, M., et al. 2020. Nanoemulsion of eucalyptus oil: An alternative to synthetic pesticides against two major storage insects, Sitophilus oryzae (L.) and Tribolium castaneum (Herbst) of rice. Industrial Crops and Products 143:111849. doi:10.1016/j.indcrop.2019.111849.

Agrafioti, P., Athanassiou, C.G., and Nayak, M.K. 2019. Detection of phosphine resistance in major stored-product insects in Greece and evaluation of a field resistance test kit. Journal of Stored Products Research 82:40-47. doi:10.1016/j.jspr.2019.02.004.

Benedetti-Ruiz, S., y Barros-Asenjo, S. 2011. Boldo (Peumus boldus Mol.) Rescate de un patrimonio forestal chileno. Manejo sustentable y valorización de sus productos. Instituto Forestal (INFOR), Santiago, Chile.

Chiffelle, I., Huerta, A., Bobadilla, V., Macuada, G., Araya, J.E., Curkovic, T., et al. 2019. Antifeedant and insecticidal effects of extracts from Melia azedarach fruits and Peumus boldus leaves on Xanthogaleruca luteola larvae. Chilean Journal of Agricultural Research 79:609-615. doi:10.4067/S0718-58392019000400609.

Chu, S.S., Hu, J.F., and Liu, Z.L. 2011. Composition of essential oil of Chinese Chenopodium ambrosioides and insecticidal activity against maize weevil, Sitophilus zeamais. Pest Management Science 67:714-718. doi:10.1002/ps.2112.

de Castro, D.S., da Silva, D.B., Tibúrcio, J.D., Sobral, M.E., Ferraz, V., Taranto, A.G., et al. 2016. Larvicidal activity of essential oil of Peumus boldus Molina and its ascaridole-enriched fraction against Culex quinquefasciatus. Experimental Parasitology 171:84-90. doi:10.1016/j.exppara.2016.10.008.

D'Almeida, R.E., Alberto, M.R., Morgan, P., Sedensky, M., and Isla, M.I. 2014. Effect of structurally related flavonoids from Zuccagnia punctata Cav. on Caenorhabditis elegans. Acta Parasitologica 60:164-172. doi:10.1515/ap-2015-0023.

Delgado-Díaz, G., y Jara, C. 2018. Actividad antihelmíntica del extracto de Peumus boldus comparada con la piperazina citrato sobre el huevo y larva de Ascaris suum. Rebiol 38:64-72. http://revistas.unitru.edu.pe/index.php/facccbiol/article/view/2150.

French, K.E. 2018. Plant-Based solutions to global livestock anthelmintic resistance. Ethnobiology Letters 9:110-123. doi:10.14237/ebl.9.2.2018.980.

González-Cortázar, M., Sánchez, E., Huicochea-Medina, M., Hernández-Velázquez, V.M., Mendoza-de-Gives, P., Zamilpa, A., et al. 2020. In vitro and in vivo nematicide effect of the extract fractions of Pleurotus djamor against Haemonchus contortus. Journal of Medicinal Food 24(3):310-318. doi:10.1089/jmf.2020.0054.

Harder,A. 2002. Milestones of helminthic research at Bayer. Parasitology Research 88:477-480. doi:10.1007/s00436-001-0551-x.

Isman, M. 2020. Commercial development of plant essential oils and their constituents as active ingredients in bioinsecticides. Phytochemistry Reviews 19:235-241. doi:10.1007/s11101-019-09653-9.

Jankowska, M., Rogalska, J., Wyszkowska, J., and Stankiewicz, M. 2018. Molecular targets for components of essential oils in the insect nervous system-a review. Molecules 23(1):34. doi:10.3390/molecules23010034. 
Junkuszew, A., Dudko, P., Gruszecki, T.M., Bojar, W., Milerski, M., Scouarnec. J.L., et al. 2017. Efficiency of various systems of antiparasitic prophylaxis in a flock of sheep. Medycyna Weterynaryjna 73:717-720. doi:10.21521/mw.5801.

Kumar, P., Mishra, S., Malik, A., and Satya, S. 2012. Housefly (Musca domestica L.) control potential of Cymbopogon citratus Stapf. (Poales: Poaceae) essential oil and monoterpenes (citral and 1,8-cineole). Parasitology Research 112(1):69-76. doi:10.1007/s00436-012-3105-5.

Liébano-Hernández, E., López-Arellano, M.E., Mendoza de Gives, P., y Aguilar-Marcelino, L. 2011. Manual de diagnóstico para la identificación de larvas de nematodos gastrointestinales en rumiantes. Manual Especial N². Centro Nacional de Investigación Disciplinaria en Parasitología Veterinaria, Instituto Nacional de Investigaciones Forestales y Agropecuarias (INIFAP), Morelos, México.

Liska, A.R., Brmez, V., Rebekie, M., and Lucie, P. 2015. Fumigant efficacy of 1,8-cineole and eugenol on the pupal stage of Tribolium castaneum (Herbst) (Insecta: Coleoptera: Tenebrionidae). Poljoprivreda 2:23-29. doi:10.18047/poljo.21.2.4

Macedo, T.F.L., Bevilaqua, M.L.C., De Oliveira, M.B.L., Camurca-Vasconcelos, L.F.A., Vieira, S.L., Oliveira, R.F., et al. 2010. Anthelmintic effect of Eucalyptus staigeriana essential oil against goat gastrointestinal nematodes. Veterinary Parasitology 173:93-98. doi:10.1016/j.vetpar.2010.06.004.

McGaughey, W.H., and Beeman, R.W. 1988. Resistance to Bacillus thuringiensis in colonies of Indian meal moth and almond moth (Lepidoptera: Pyralidae). Journal of Economic Entomology 81(1):28-33. doi:10.1093/jee/81.1.28.

Mesterházy, A., Oláh, J., and Popp, J. 2020. Losses in the grain supply chain: causes and solutions. Sustainability 12:2342. doi:10.3390/su12062342.

Oliveira, G., Vieira, T., Nunes, V., Ruas, M., Duarte, E., Moreira, D., et al. 2014. Chemical composition and efficacy in the egg-hatching inhibition of essential oil of Piper aduncum against Haemonchus contortus from sheep. Revista Brasileira de Farmacognosia 24:288-292. doi:10.1016/j.bjp.2014.07.004.

Pang, X., Feng, Y.X., Qi, X.J., Wang, Y., Almaz, B., Xi, C., et al. 2019. Toxicity and repellent activity of essential oil from Mentha piperita Linn. leaves and its major monoterpenoids against three stored product insects. Environmental Science and Pollution Research 27:7618-7627. doi:10.1007/s11356-019-07081-y.

Pavela, R., Benelli, G., Petrelli, R., Cappellacci, L., Lupidi, G., Sut, S., et al. 2019. Exploring the insecticidal potential of boldo (Peumus boldus) essential oil: Toxicity to pests and vectors and non-target impact on the microcrustacean Daphnia magna. Molecules 24(5):879. doi:10.3390/molecules24050879.

Pessoa, L.M., Morais, S.M., Bevilaqua, C.M.L., and Luciano, J.H.S. 2002. Anthelmintic activity of essential oil of Ocimum gratissimum Linn. and eugenol against Haemonchus contortus. Veterinary Parasitology 109:59-63. doi:10.1016/S0304-4017(02)00253-4.

Pineda-Alegría, J.A., Sánchez-Vázquez, J.E., González-Cortazar, M., Zamilpa, A., López-Arellano, M.E., Cuevas-Padilla, E.J., et al. 2017. The edible mushroom Pleurotus djamor produces metabolites with lethal activity against the parasitic nematode Haemonchus contortus. Journal of Medicinal Food 20(12):1184-1192. doi:10.1089/jmf.2017.0031.

Pizarro, D., Silva, G., Tapia, M., Rodríguez, J.C., Urbina, A., Figueroa, I., et al. 2014. Aceite esencial de follaje de Peumus boldus Molina colectado en otoño para el control del gorgojo del maíz Sitophilus zeamais Motschulsky. Chilean Journal of Agricultural and Animal Sciences 30:171-180. http://agro-ciencia.cl/images/revistas/2014/v30n3a02.pdf.

Ribeiro, W.L., Macedo, A.T., dos Santos, J.M., Oliveira, E.F., Camurça-Vasconcelos, A.L., de Paula, H.C., et al. 2013. Activity of chitosan-encapsulated Eucalyptus staigeriana essential oil on Haemonchus contortus. Experimental Parasitology 135:24-29. doi:10.1016/j.exppara.2013.05.014.

Sombra K.E.S., de Aguiar, C.V.S., de Oliveira, S.J., Barbosa, M.G., Zocolo G.J., and Pastori, P.L. 2020. Potential pesticide of three essential oils against Spodoptera frugiperda (J.E. Smith) (Lepidoptera: Noctuidae). Chilean Journal of Agricultural Research 80:617-628. doi:10.4067/S0718-58392020000400617.

Squires, M.J., Foster, G.J., Lindsay, S.D., Caudel, L.D., and Zajac, M.A. 2010. Efficacy of an orange oil emulsion as an anthelmintic against Haemonchus contortus in gerbils (Meriones unguiculatus) and sheep. Veterinary Parasitology 172:9599. doi:10.1016/j.vetpar.2010.04.017.

Tak, J., and Isman, M.B. 2015. Enhanced cuticular penetration as the mechanism for synergy of insecticidal constituents of Rosemary essential oil in Trichoplusia ni. Scientific Reports 5:12690. doi:10.1038/srep12690.

Vargas-Magaña, J.J., Torres-Acosta, J.F.J., Aguilar-Caballero, A.J., Sandoval-Castro, C.A., Hoste, H., and Chan-Perez, J.I. 2014. Anthelmintic activity of acetone-water extracts against Haemonchus contortus eggs: interactions between tannins and other plant secondary compounds. Veterinary Parasitology 206:322-327. doi:10.1016/j.vetpar.2014.10.008.

Xie, F., Husain, S., and Zeng, X. 2019. Fumigant toxicity and biochemical properties of $(\alpha+\beta)$ thujone and 1,8-cineole derived from Seriphidium brevifolium volatile against the red imported fire ant Solenopsis invicta (Hymenoptera: Formicidae). Brazilian Journal of Farmacognosy 29:720-727. doi:10.1016/j.bjp.2019.04.013.

Zhu, L., Dai, J., Yang, Li., and Qiu, J. 2013. Anthelmintic activity of Arisaema franchetianum and Arisaema lobatum essential oils against Haemonchus contortus. Journal of Ethnopharmacology 148:311-316. doi:10.1016/j.jep.2013.04.034.

Zhu, W.X., Zhao, K., Chu, S.S., and Liu, Z.L. 2012. Evaluation of essential oil and its three main active ingredients of Chinese Chenopodium ambrosioides (Family: Chenopodiaceae) against Blatella germanica. Journal of Arthropod Borne Disease 6:90-97. https://www.ncbi.nlm.nih.gov/pmc/articles/PMC3547299/. 